\title{
PENGARUH PROMOSI, HARGA DAN PELAYANAN TERHADAP KEPUTUSAN PEMBELIAN PADA TIKI TEGAL PARANG A258P JAKARTA
}

\author{
Turmono ${ }^{1}$ \\ Ahmad Fairuz ${ }^{2}$ \\ ${ }^{1,2}$ Program Studi Manajemen STIE Dharma Bumiputera
}

Email: $\underline{\text { urmono217@gmail.com }}^{1}$, iyutguevara@gmail.com ${ }^{2}$

\begin{abstract}
ABSTRAK
Penelitian ini bertujuan untuk menganalisis pengaruh promosi, harga dan pelayanan terhadap keputusan pembelian pada TIKI Tegal Parang A258 Jakarta. Metode penelitian yang dipergunakan ialah metode penelitian kuantitatif dengan analisis statistik parametrik berupa regresi linear berganda. Penelitian ini mempergunakan data primer yang diambil dari hasil jawaban kuesioner yang disebarkan kepada 50 responden. Hasil analisis data dengan mengunakan alat bantu pengolahan data software SPSS 23 menunjukkan bahwa ketiga variabel bebas, yakni promosi, harga, dan pelayanan, secara parsial berpengaruh positif dan signifikan terhadap variabel keputusan pembelian.
\end{abstract}

Kata kunci: Promosi, harga, pelayanan, keputusan pembelian

\section{ABSTRACT}

This study aims to analyze the effect of promotion, price and service on purchasing decisions on TIKI Tegal Parang A258 Jakarta. The research method used is a quantitative research method with parametric statistical analysis in the form of multiple linear regression. This study uses primary data drawn from the results of questionnaire responses distributed to 50 respondents. The results of data analysis using SPSS 23 data processing aids showed that the three independent variables, namely promotion, price, and service, partially had a positive and significant effect on purchasing decision variables.

Keywords: Promotion, price, service, purchasing decisions

\section{PENDAHULUAN}

Penggunaan jasa pengiriman saat ini telah menjadi pilihan alternatif masyarakat dalam mengirimkan barang dan dokumen ke berbagai daerah. Hal tersebut terjadi karena penggunaan jasa pengiriman dinilai lebih efektif dan efisien dalam mengirimkan barang dan dokumen. Dalam sistem perdagangan saat ini, transaksi jual-beli online sudah umum dipergunakan dimana transaksi tersebut menghubungkan penjual dengan konsumennya dari jarak jauh, sehingga membuat jasa pengiriman semakin banyak digunakan dalam pengiriman barang. Akibatnya, persaingan di industri jasa pengiriman pun semakin ketat. 
Salah satu perusahaan jasa pengiriman yang ada di Indonesia adalah PT Citra Van Titipan Kilat (TIKI). Saat ini, TIKI merupakan satu di antara beberapa perusahaan jasa pengiriman terbesar yang tersebar di seluruh daerah di Indonesia. Dengan persaingan yang semakin ketat, TIKI pun terus bersaing dan berupaya untuk mendapatkan sebanyakbanyaknya pelanggan yang menggunakan jasa pengirimannya. Dalam kaitannya dengan hal ini, ada beberapa variabel penting yang dapat dioptimalisasi untuk meningkatkan keputusan pembelian pada TIKI Tegal Parang A258 Jakarta.

Pada umumnya, konsumen itu sendiri akan memperhatikan terlebih dahulu harga yang diberikan oleh beberapa perusahaan jasa pengiriman sebelum akhirnya memutuskan untuk menggunakan jasa pengiriman dari perusahaan yang paling dikehendakinya. Sejalan dengan hal ini, Masturi dan Hardini (2017) berpendapat bahwa harga yang ekonomis cenderung mampu untuk lebih menarik minat beli konsumen. Lebih lanjut, Masturi dan Hardini (2017) juga menjelaskan bahwa banyak konsumen akan lebih tertarik untuk membeli produk dengan harga bersaing yang juga sebanding dengan manfaatnya.

Berikut ini ialah perbandingan harga TIKI Tegal Parang A258 Jakarta dengan JNE Tegal Parang Gita Mandiri Jakarta selaku pesaingnya.

Tabel 1. Daftar Tarif Layanan TIKI Tegal Parang A258

\begin{tabular}{|c|c|c|c|c|c|c|c|c|c|c|c|}
\hline \multirow{2}{*}{$\begin{array}{l}\text { No } \\
1 \\
\end{array}$} & \multirow[t]{2}{*}{ Layanan } & \multicolumn{2}{|c|}{$\begin{array}{c}\text { Tarif Per } 1 \mathrm{Kg} \\
\text { Jabodetabek }\end{array}$} & \multirow{2}{*}{$\frac{\text { Estimasi }}{2 \text { Hari }}$} & $\begin{array}{c}\text { Tarif Naik } \\
\text { Per } 1 \text { kg }\end{array}$ & \multicolumn{2}{|c|}{$\begin{array}{c}\text { Tarif Luar } \\
\text { Jabodetabek Per } 1 \mathrm{Kg}\end{array}$} & \multirow{2}{*}{$\begin{array}{c}\text { Estimasi } \\
3 \text { Hari } \\
\end{array}$} & \multicolumn{2}{|c|}{$\begin{array}{c}\text { Tarif Luar } \\
\text { Negeri Per } 1 \mathrm{Kg}\end{array}$} & \multirow{2}{*}{$\begin{array}{r}\text { Estimasi } \\
3 \text { Hari }\end{array}$} \\
\hline & & $\mathrm{Rp}$ & 9,000 & & Rp $\quad 9,000$ & $\mathrm{Rp}$ & 27,000 & & $\mathrm{Rp}$ & 44,000 & \\
\hline 2 & ECO & $\mathrm{Rp}$ & 6,000 & 4 Hari & Rp $\quad 6,000$ & $\mathrm{Rp}$ & 23,000 & 5 Hari & $\mathrm{Rp}$ & 38,000 & 5 Hari \\
\hline 3 & ONS & $\mathrm{Rp}$ & 15,000 & 1 Hari & Rp 15,000 & & & - & & - & - \\
\hline 4 & SDS & $\mathrm{Rp}$ & 156,000 & Same Day & Rp 21,000 & & & - & & - & - \\
\hline 5 & $\mathrm{HDS}$ & $\mathrm{Rp}$ & 37,000 & 1 Hari & Rp 21,000 & & & - & & - & - \\
\hline 6 & TRC & $\mathrm{Rp}$ & 25,000 & 4 Hari & - & & & - & & - & - \\
\hline
\end{tabular}

Sumber Data : TIKI Tegal Parang A258

Tabel 2. Daftar Tarif Layanan JNE Tegal Parang Gita Mandiri

\begin{tabular}{|c|c|c|c|c|c|c|c|c|}
\hline \multirow{2}{*}{$\begin{array}{c}\text { No } \\
1 \\
\end{array}$} & Layanan & \multicolumn{2}{|c|}{$\begin{array}{l}\text { Tarif Per } 1 \text { Kg } \\
\text { Jabodetabek }\end{array}$} & \multirow{2}{*}{$\begin{array}{c}\text { Estimasi } \\
\text { 4-4 Hari }\end{array}$} & \multirow{2}{*}{$\begin{array}{c}\text { Tarif Naik } \\
\text { Per } 1 \text { kg } \\
- \\
\end{array}$} & \multicolumn{2}{|c|}{$\begin{array}{c}\text { Tarif Luar } \\
\text { Jabodetabek Per } 1 \text { Kg }\end{array}$} & \multirow{2}{*}{$\begin{array}{l}\text { Estimasi } \\
6-6 \text { Hari }\end{array}$} \\
\hline & JTR & $\mathrm{Rp}$ & 25,000 & & & $\mathrm{Rp}$ & 60.000 & \\
\hline 2 & JTR 250 & $\mathrm{Rp}$ & 350,000 & 4-4 Hari & - & $\mathrm{Rp}$ & 1.500 .000 & 6-6 Hari \\
\hline 3 & JTR $<150$ & $\mathrm{Rp}$ & 200,000 & 4-4 Hari & - & $\mathrm{Rp}$ & 850.000 & 6-6 Hari \\
\hline 4 & JTR > 250 & $\mathrm{Rp}$ & 500,000 & 4-4 Hari & - & $\mathrm{Rp}$ & 2.100 .000 & 6-6 Hari \\
\hline 5 & OKE & $\mathrm{Rp}$ & 8,000 & 3-3 Hari & Rp 8,000 & $\mathrm{Rp}$ & 23.000 & 6-6 Hari \\
\hline 6 & POPBOX & $\mathrm{Rp}$ & 18,000 & 1-1 Hari & Rp 18,000 & & & \\
\hline 7 & REG & $\mathrm{Rp}$ & 9,000 & 2-2 Hari & $\begin{array}{ll}\mathrm{Rp} & 9,000 \\
\end{array}$ & $\mathrm{Rp}$ & 26.000 & 3-3 Hari \\
\hline 8 & SPS & $\mathrm{Rp}$ & 60,000 & Same Day & $\mathrm{Rp} 30,000$ & & - & - \\
\hline 9 & YES & $\mathrm{Rp}$ & 18,000 & 1-1 Hari & $\operatorname{Rp} 18,000$ & & - & - \\
\hline $\mathbf{1 0}$ & INTERNASIONAL & & - & - & - & & - & - \\
\hline
\end{tabular}

Sumber Data : JNE Tegal Parang Gita Mandiri 
Berdasarkan tabel di atas, dapat dilihat bahwa tarif TIKI dan JNE, terutama pada jangkauan Jabodetabek, dengan estimasi waktu yang sama memiliki perbedaan harga yang tidak terlalu jauh. Bahkan pada pengiriman regular dengan estimasi waktu 2 hari, tarif layanan dari kedua perusahaan jasa ekspedisi tersebut memiliki harga yang sama untuk jangkauan Jabodetabek. Akan tetapi, TIKI menetapkan tarif yang lebih mahal dibanding JNE pada pengiriman dengan estimasi Same Day untuk jangkauan Jabodetabek meskipun dalam pengiriman dengan estimasi 1 hari, TIKI menawarkan harga yang lebih murah daripada JNE. Dalam kaitannya dengan upaya peningkatan keputusan pembelian, signifikansi pengaruh kebijakan harga sebagaimana pada tabel 1 tersebut terhadap keputusan pembelian itu sendiri perlu dianalisis lebih lanjut.

Keputusan pembelian juga dapat dipengaruhi oleh variabel promosi. Hal ini telah dibuktikan oleh Haryoko (2017) dalam penelitiannya yang menunjukkan bahwa promosi mampu mempengaruhi keputusan pembelian secara positif dan signifikan. Selain itu, bagi perusahaan yang secara khusus bergerak di bidang jasa, faktor pelayanan juga muncul sebagai variabel lain yang sangat penting. Dalam hal ini, Rizaldi dan Hardini (2018) menjelaskan bahwa pelayanan yang berkualitas tinggi akan mampu memberikan kepuasan bagi konsumen. Dengan kata lain, kualitas pelayanan tidak hanya mampu mempengaruhi konsumen untuk melakukan keputusan pembelian, tetapi juga mampu untuk memuaskan konsumen tersebut hingga akhirnya bahkan mampu mengkonversi konsumen yang bersangkutan untuk menjadi pelanggan yang loyal. Hal tersebut telah dibuktikan oleh hasil penelitian yang dilakukan oleh Amrullah, dkk. (2016) yang menunjukkan bahwa kualitas pelayanan berpengaruh positif dan signifikan terhadap keputusan pembelian.

Berdasarkan latar belakang di atas, perlu dilakukan penelitian yang menganalisis pengaruh promosi, harga dan pelayanan terhadap keputusan pembelian pada TIKI Tegal Parang A258 Jakarta.

\section{TINJAUAN PUSTAKA}

\section{Keputusan Pembelian}

Menurut Sumarwan (2018), konsumen melakukan pengambilan keputusan secara rutin di setiap hari, setiap minggu, setiap bulan, atau bahkan setiap tahun sekali. Keputusan pembelian itu sendiri oleh Schiffman dan Kanuk (2008) didefinisikan sebagai suatu kegiatan memilih dari dua atau lebih alternatif pembelian yang tersedia. Adapun Kotler 
dan Armstrong (2012) mengartikan keputusan pembelian sebagai kegiatan membeli merek yang paling disukai di antara beberapa alternatif yang ada. Berdasarkan pendapat para ahli di atas, keputusan pembelian dapat disintesakan sebagai suatu pemilihan dari beragam alternatif untuk mendapatkan sesuatu yang tepat dan memuaskan.

Secara garis besar, Tjiptono (2017:53) mengkategorikan proses terkait keputusan pembelian ke dalam tiga tahapan utama, yakni sebagai berikut.

1. Tahap pra-pembelian, yakni tahapan yang meliputi seluruh aktivitas konsumen yang terjadi sebelum transaksi pembelian dan penggunaan produk. Tahapan ini mencakup tiga proses, yakni pengidentifikasian kebutuhan, pencarian informasi, dan pengevaluasian alternatif.

2. Tahap konsumsi, yakni tahapan dimana konsumen melakukan pembelian dan penggunaan terhadap barang/jasa.

3. Tahap evaluasi purnabeli, yakni tahapan dimana konsumen menentukan apakah keputusan pembelian yang diambilnya adalah keputusan yang tepat.

\section{Promosi}

Menurut Blythe (2008), promosi merupakan bauran pemasaran yang keempat. Secara luas, promosi merupakan suatu komunikasi terpadu, yakni komunikasi antara perusahaan dan konsumennya. Adapun dalam arti sempit, promosi merupakan promosi penjualan atau pemberian insentif, yakni sesuatu yang diberikan kepada konsumen ataupun saluran pemasaran dalam upaya mendorong konsumen dan saluran pemasaran tersebut untuk membeli dan menjual lebih banyak produk. Dalam hal ini, insentif yang diberikan kepada konsumen disebut juga sebagai promosi konsumen, sedangkan insentif yang diberikan kepada saluran pemasaran disebut juga sebagai promosi dagang (Sumarwan, 2017).

Menurut Keegan (2002) dalam Fauzi (2017:72), promosi merujuk pada seluruh bentuk komunikasi yang digunakan organisasi untuk menginformasikan sesuatu dan mempengaruhi tingkah laku pembelian pelanggan yang ada serta pelanggan potensial. Berdasarkan pendapat para ahli di atas, promosi dapat disintesakan sebagai suatu bentuk komunikasi yang dilakukan oleh sebuah organisasi atau perusahaan dengan jalan mempengaruhi konsumen secara langsung ataupun tidak langsung untuk meningkatkan omzet penjualan. 
Menurut Tjiptono (2017:399), terdapat lima bentuk dalam komunikasi pemasaran, yakni sebagai berikut.

1. Periklanan, yaitu seluruh bentuk presentasi dan promosi ide dan barang/jasa yang dibayar oleh sponsor yang telah teridentifikasi.

2. Promosi penjualan, yakni seluruh bentuk insentif jangka pendek yang ditujukan untuk mendorong percobaan atau pembelian terhadap suatu produk.

3. Public relations, yakni seluruh bentuk program yang didesain untuk mempromosikan dan melindungi citra dari suatu perusahaan ataupun produk individualnya.

4. Penjualan pribadi, yakni suatu interaksi tatap muka dengan calon pembeli yang ditujukan untuk melakukan suatu presentasi, menjawab pertanyaan terkait, dan mendapatkan pesanan.

5. Pemasaran online, yakni penggunaan surat, telepon, fax, e-mail, ataupun internet untuk secara langsung berkomunikasi dengan pelanggan ataupun untuk mendapatkan reaksi dari pelanggan dan pelanggan potensial secara langsung dan spesifik.

\section{Harga}

Menurut Fauzi (2017:58), harga merupakan nilai tukar atas manfaat dari suatu produk yang biasanya dinyatakan dalam satuan moneter. Dalam hal ini, harga adalah jumlah uang yang dibebankan atas suatu produk. Dari perspektif produsen, harga merupakan nilai barang yang bisa memberi manfaat bagi pencapaian tujuan organisasi, memberi laba, mengatasi persaingan, dan sebagainya, sementara dari perspsektif konsumen, harga merupakan nilai barang yang bisa memberi manfaat atas pemenuhan kebutuhan dan keinginannya.

Oentoro (2012) dalam Sudaryono (2014:361) mendefinisikan harga sebagai nilai tukar yang bisa dipersamakan dengan uang ataupun barang lain untuk manfaat yang diperoleh dari suatu produk bagi seseorang ataupun sekelompok orang pada waktu dan tempat tertentu. Berdasarkan pendapat para ahli di atas, harga dapat disintesakan sebagai nilai yang harus dikeluarkan oleh konsumen untuk dapat memiliki, merasakan dan menggunakan atau mengkonsumsi suatu barang dan jasa guna mendapatkan kepuasan.

Dalam mencirikan harga, Kotler dan Armstrong (2012:278) mengemukakan empat indikator sebagai berikut. 
1. Keterjangkauan harga

2. Harga sesuai kemampuan atau daya saing harga

3. Kesesuaian harga dengan kualitas produk

4. Kesesuaian harga dengan manfaat

\section{Pelayanan}

Kotler (1996:467) dalam Nasution (2015:64) mendefinisikan pelayanan (service) sebagai suatu kegiatan ataupun manfaat yang ditawarkan oleh satu pihak kepada pihak lainnya yang pada dasarnya tidak berwujud dan tidak pula menghasilkan kepemilikan apapun. Menurut Assauri (2015:213), kesuksesan pemasaran suatu produk sangatlah ditentukan oleh baik tidaknya pelayanan yang diberikan perusahaan dalam memasarkan produknya tersebut. Dalam pemasaran produk, pelayanan yang diberikan itu sendiri meliputi pelayanan saat penawaran produk, pelayanan dalam jual-beli produk itu, pelayanan saat penyerahan produk yang dijual yang juga meliputi pengangkutan yang ditanggung penjual, instalasi produk tersebut, dan asuransi ataupun jaminan atas risiko kerusakan barang dalam perjalanan dan dalam jangka waktu tertentu setelah pembelian produk oleh konsumen, serta pemeliharaan dan perbaikan produk tersebut jika terjadi kerusakan. Berdasarkan pendapat para ahli di atas, pelayanan dapat disintesakan sebagai suatu upaya berupa komunikasi atau tindakan yang diberikan oleh perusahaan guna memberikan nilai tambahan.

Menurut Parasuraman, et al. (1988) dalam Tjiptono dan Chandra (2016:137), terdapat lima dimensi pelayanan, yakni sebagai berikut.

1. Keandalan (Reliability)

Dimensi ini berhubungan dengan kemampuan perusahaan dalam melayani secara akurat dengan tanpa membuat kesalahan apapun dan dalam menyampaikan jasanya sesuai waktu yang telah disepakati.

2. Daya Tanggap (Responsiveness)

Dimensi ini berhubungan dengan kesediaan dan kemampuan dalam membantu pelanggan dan menanggapi permintaan mereka, memberitahukan waktu mengenai kapan jasa akan diberikan, serta kemudian memberikan jasa yang dimaksud secara cepat. 
3. Jaminan (Assurance)

Dimensi ini berhubungan dengan perilaku karyawan yang dapat menimbulkan kepercayaan pelanggan terhadap perusahaan dan kemampuan perusahaan dalam menciptakan rasa aman bagi pelanggannya. Dari perspektif dimensi ini, karyawan juga harus senantiasa bersikap sopan, serta menguasai pengetahuan dan keterampilan yang dibutuhkan untuk menangani setiap masalah pelanggan.

4. Empati (Empathy)

Berkaitan dengan dimensi ini, perusahaan harus mampu dalam memahami masalah pelanggannya, mampu untuk bertindak demi kepentingan pelanggannya tersebut, mampu memberi perhatian secara personal kepada mereka, dan juga memiliki jam operasional yang nyaman.

5. Berwujud (Tangibles)

Dimensi ini berhubungan dengan dengan daya tarik dari fasilitas fisik, perlengkapan, dan material yang dipergunakan perusahaan, serta penampilan dari para karyawan.

\section{Keterkaitan Antarvariabel Penelitian}

\section{Keterkaitan antara Promosi dan Keputusan Pembelian}

Keputusan pembelian dapat dipengaruhi oleh variabel promosi sebagaimana yang telah dibuktikan oleh Haryoko (2017) dalam penelitiannya yang menunjukkan bahwa promosi mampu mempengaruhi keputusan pembelian secara positif dan signifikan. Hal tersebut terjadi karena promosi akan membantu perusahaan dalam mengkomunikasikan produknya secara terpadu kepada konsumen, sehingga pada akhirnya mampu mendorong konsumen tersebut untuk membeli dan menggunakan produk yang bersangkutan. Dengan kata lain, promosi yang dilakukan oleh suatu perusahaan mampu mendorong konsumen untuk mengambil keputusan pembelian terhadap produk yang dipromosikan tersebut, termasuk produk dalam bentuk jasa.

$\mathrm{H}_{1}$ : Promosi berpengaruh positif dan signifikan terhadap keputusan pembelian pada TIKI Tegal Parang A258 Jakarta

\section{Keterkaitan antara Harga dan Keputusan Pembelian}

Hasil penelitian yang dilakukan oleh Masturi dan Hardini (2017) menunjukkan bahwa harga berpengaruh positif dan signifikan terhadap keputusan pembelian. Hal 
tersebut mencerminkan bahwa pada umumnya, konsumen akan memperhatikan terlebih dahulu harga yang diberikan oleh beberapa perusahaan di industri yang sejenis sebelum akhirnya memutuskan untuk menggunakan produk (barang/jasa) yang ditawarkan oleh satu perusahaan yang paling dikehendakinya. Dalam hal ini, Masturi dan Hardini (2017) berpendapat bahwa harga yang ekonomis cenderung mampu untuk lebih menarik minat beli konsumen. Keduanya menjelaskan bahwa banyak konsumen akan lebih tertarik untuk membeli produk dengan harga bersaing yang juga sebanding dengan manfaatnya.

$\mathrm{H}_{2}$ : Harga berpengaruh positif dan signifikan terhadap keputusan pembelian pada TIKI Tegal Parang A258 Jakarta

\section{Keterkaitan antara Pelayanan dan Keputusan Pembelian}

Keputusan pembelian dapat dipengaruhi oleh pelayanan secara positif dan signifikan sebagaimana yang telah dibuktikan oleh Amrullah, dkk. (2016). Dalam hal ini, Sari dan Lestari (2019) menjelaskan bahwa konsumen akan merasa puas jika menerima pelayanan yang baik serta sesuai dengan ekspektasinya karena hal itu menunjukkan bahwa perusahaan menghargai konsumen tersebut dan selalu berupaya untuk memenuhi kebutuhan dan keinginannya yang salah satunya diwujudkan melalui pemberian pelayanan yang prima. Oleh sebab itu, konsumen cenderung untuk melakukan pembelian pada perusahaan dengan pelayanan prima yang dinilainya paling sesuai dengan ekspektasinya.

$\mathrm{H}_{3}$ : Pelayanan berpengaruh positif dan signifikan terhadap keputusan pembelian pada TIKI Tegal Parang A258 Jakarta

\section{Kerangka Pemikiran}

Kerangka pemikiran dari penelitian ini dapat dilihat dari gambar sebagai berikut. 


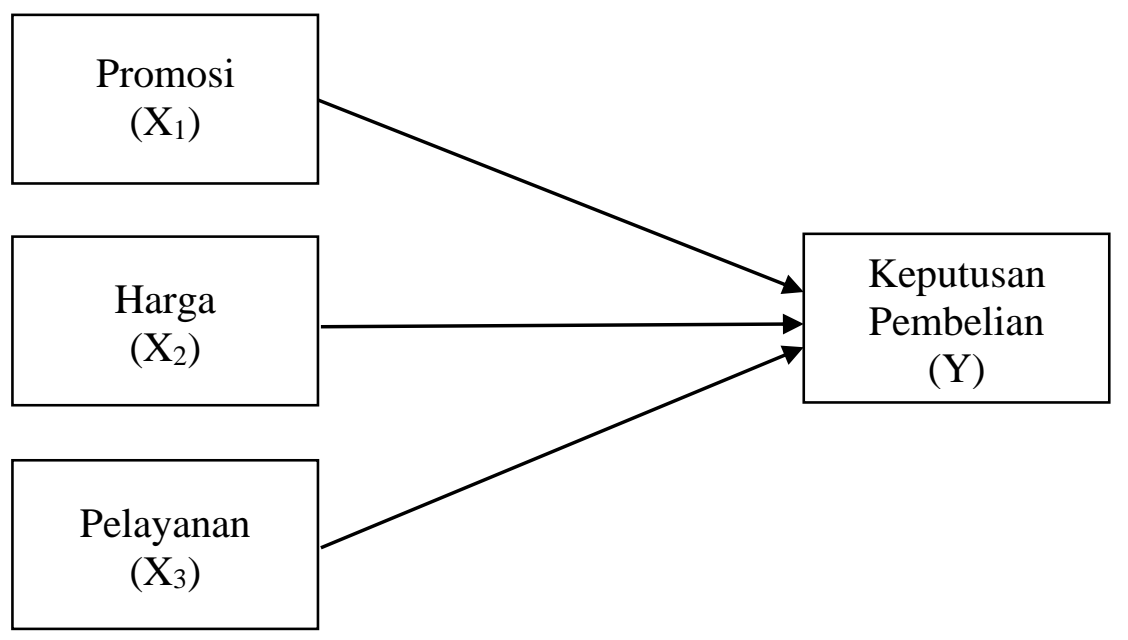

Gambar 1. Kerangka Pemikiran

\section{METODOLOGI PENELITIAN}

\section{Jenis dan Sumber Data}

Penelitian ini mempergunakan data primer berjenis cross section yang diambil dari hasil jawaban kuesioner yang disebarkan kepada responden.

\section{Populasi dan Sampel}

Populasi dalam penelitian ini adalah 100 orang yang pernah menggunakan jasa TIKI Tegal Parang A258 sebanyak 2 kali atau lebih. Berdasarkan jumlah populasi tersebut, maka banyaknya sampel yang dipergunakan dalam penelitian ini adalah 50 orang. Jumlah tersebut dihitung dengan menggunakan rumus sebagai berikut.

$$
\mathrm{n}=\frac{N}{1+\left(N x e^{2}\right)}
$$

Keterangan:

$$
\begin{aligned}
\mathrm{n}= & \text { Ukuran sampel } \\
\mathrm{N}= & \text { Jumlah populasi } \\
\mathrm{e} \quad= & \text { Persentase kelonggaran ketidakterikatan karena kesalahan pengambil } \\
& \text { sampel yang masih di inginkan } 10 \%(0,1)
\end{aligned}
$$




\section{Metode Analisis}

Penelitian ini mempergunakan metode analisis regresi linear berganda dengan alat bantu pengolahan data berupa software SPSS 23 untuk menganalisis pengaruh parsial dari ketiga variabel bebas, yakni variabel promosi, harga, dan pelayanan, terhadap variabel independen yang berupa variabel keputusan pembelian.

\section{HASIL DAN PEMBAHASAN}

\section{Deskripsi Data Penelitian}

\section{Karakteristik Responden Berdasarkan Jenis Kelamin}

Karakteristik responden penelitian ini berdasarkan jenis kelaminnya dapat dilihat pada tabel berikut.

Tabel 3. Karakteristik Responden Berdasarkan Jenis Kelamin

\begin{tabular}{|c|c|c|c|}
\hline No. & Jenis Kelamin & Jumlah & Persentase (\%) \\
\hline 1 & Laki-Laki & 23 & $46 \%$ \\
\hline 2 & Perempuan & 27 & $54 \%$ \\
\hline & Jumlah & 50 & $100 \%$ \\
\hline
\end{tabular}

(Sumber: Data diolah, 2019)

\section{Karakteristik Responden Berdasarkan Usia}

Karakteristik responden penelitian ini berdasarkan usianya dapat dilihat pada tabel berikut.

Tabel 4. Karakteristik Responden Berdasarkan Usia

\begin{tabular}{|c|c|c|c|}
\hline No. & Usia & Jumlah & Persentase (\%) \\
\hline 1 & $<21$ Tahun & 16 & $32 \%$ \\
\hline 2 & $21-30$ Tahun & 30 & $60 \%$ \\
\hline 3 & $31-40$ Tahun & 1 & $2 \%$ \\
\hline 4 & $41-50$ Tahun & 1 & $2 \%$ \\
\hline 5 & $>50$ Tahun & 2 & $4 \%$ \\
\hline & Jumlah & 50 & $100 \%$ \\
\hline
\end{tabular}

(Sumber: Data diolah, 2019)

\section{Karakteristik Responden Berdasarkan Pendidikan}

Karakteristik responden penelitian ini berdasarkan pendidikannya dapat dilihat pada tabel berikut. 
Tabel 5. Karakeristik Responden Berdasarkan Pendidikan

\begin{tabular}{|c|c|c|c|}
\hline No. & Pendidikan & Jumlah & Persentase (\%) \\
\hline 1 & SMP & 2 & $4 \%$ \\
\hline 2 & SMA & 33 & $66 \%$ \\
\hline 3 & S1 & 13 & $26 \%$ \\
\hline 4 & Magister & 2 & $4 \%$ \\
\hline & Jumlah & 50 & $100 \%$ \\
\hline
\end{tabular}

(Sumber: Data diolah, 2019)

\section{Karakteristik Responden Berdasarkan Pekerjaan}

Karakteristik responden penelitian ini berdasarkan pekerjaannya dapat dilihat pada tabel berikut.

Tabel 6. Karakteristik Responden Berdasarkan Pekerjaan

\begin{tabular}{|c|c|c|c|}
\hline No. & Pekerjaan & Jumlah & Persentase (\%) \\
\hline 1 & Pelajar/ Mahasiswa/i & 30 & $60 \%$ \\
\hline 2 & Karyawan Swasta & 15 & $30 \%$ \\
\hline 3 & Wirausaha & 2 & $4 \%$ \\
\hline 4 & Pegawai Negeri & 2 & $4 \%$ \\
\hline 5 & Pengangguran & 1 & $2 \%$ \\
\hline & Jumlah & 50 & $100 \%$ \\
\hline
\end{tabular}

(Sumber: Data diolah, 2019)

\section{Karakteristik Responden Berdasarkan Pendapatan}

Karakteristik responden penelitian ini berdasarkan pendapatannya dapat dilihat pada tabel berikut.

Tabel 7. Karakteristik Responden Berdasarkan Pendapatan

\begin{tabular}{|c|c|c|c|}
\hline No. & Pendapatan & Jumlah & Persentase (\%) \\
\hline 1 & $<\mathrm{Rp} \mathrm{1.500.000}$ & 27 & $54 \%$ \\
\hline 2 & $\mathrm{Rp} \mathrm{1.500.000-Rp} \mathrm{3.000.000}$ & 12 & $24 \%$ \\
\hline 3 & $\mathrm{Rp} \mathrm{3.000.000-Rp} \mathrm{5.000.000}$ & 6 & $12 \%$ \\
\hline 4 & $>\operatorname{Rp~5.000.000}$ & 5 & $10 \%$ \\
\hline & Jumlah & 50 & $100 \%$ \\
\hline
\end{tabular}

(Sumber: Data diolah, 2019)

\section{Hasil Uji Instrumen}

Instrumen yang dipergunakan dalam penelitian ini telah memenuhi syarat validitas dan reliabilitas berdasarkan hasil pengujian instrumen yang bersangkutan. 


\section{Hasil Uji Asumsi Klasik}

\section{Hasil Uji Normalitas}

Hasil uji One Sample Kolmogorov-Smirnov dari data yang dipergunakan dalam penelitian ini menunjukkan nilai Asymp. Sig. (2-tailed) sebesar 0,200>0,05. Hal tersebut mencerminkan bahwa nilai residual terstandarisasi dinyatakan menyebar secara normal, sehingga dengan kata lain, data yang dipergunakan dalam penelitian ini pun terdistribusi normal.

\section{Hasil Uji Multikolinearitas}

Hasil uji multikolonieritas menunjukkan bahwa ketiga variabel bebas yang dipergunakan dalam penelitian ini memiliki nilai tolerance $>0,1$ dan nilai VIF $<10$, sehingga tidak terjadi gejala multikolineritas pada model regresi yang terbentuk.

\section{Hasil Uji Autokorelasi}

Pengujian autokorelasi menghasilkan nilai Asymp. Sig. (2-tailed) sebesar 0,991 > 0,05 . Hal tersebut menunjukan bahwa tidak terjadi autokorelasi dalam model regresi yang dibangun.

\section{Hasil Uji Heteroskedastisitas}

Hasil uji heteroskedastisitas menunjukkan bahwa data titik-titik menyebar secara acak di atas maupun di bawah angka nol pada sumbu Regresion Studentized Residual atau dengan kata lain, tidak berkumpul di satu tempat serta tidak membentuk pola tertentu. Oleh sebab itu, dapat disimpulkan bahwa tidak terjadi gejala heteroskedastisitas pada model regresi yang terbentuk.

\section{Hasil Uji Regresi Linear Berganda}

Persamaan dari model regresi linear berganda yang dipergunakan dalam penelitian ini dapat dinyatakan sebagai berikut.

$$
\mathrm{Y}=2,187+0,239 \mathrm{X} 1+0,381 \mathrm{X} 2+0,317 \mathrm{X3}+\mathrm{e}
$$

Keterangan:

$\mathrm{Y} \quad=$ Keputusan pembelian 


$$
\begin{array}{ll}
\mathrm{X}_{1} & =\text { Promosi } \\
\mathrm{X}_{2} & =\text { Harga } \\
\mathrm{X}_{3} & =\text { Pelayanan } \\
\mathrm{e} & =\text { Tingkat kesalahan }
\end{array}
$$

\section{Hasil Uji F}

Hasil uji $\mathrm{F}$ menunjukkan adanya nilai signifikansi sebesar 0,000 $<0,05$ yang mencerminkan bahwa model regresi yang dibangun dapat digunakan untuk memprediksi variabel terikat, yakni variabel keputusan pembelian atau dengan kata lain, variabel promosi, harga, dan pelayanan secara simultan berpengaruh signifikan terhadap keputusan pembelian.

\section{Hasil Uji Koefisien Determinasi}

Besarnya nilai Adjusted $R$ Square dari model regresi ini adalah 0,659. Hal tersebut menunjukkan bahwa besarnya kontribusi variabel promosi, harga, dan pelayanan dalam mempengaruhi variabel keputusan pembelian adalah 65,90\% dengan 34,10\% sisanya diipengaruhi oleh faktor-faktor lain yang tidak diteliti dalam model penelitian ini.

\section{Hasil Uji Parsial (Uji t)}

Pada variabel promosi, hasil uji t menunjukkan adanya nilai signifikan sebesar $0,031<0,05$ yang dengan kata lain mencerminkan bahwa variabel promosi tersebut berpengaruh positif dan signifikan terhadap keputusan pembelian pada TIKI Tegal Parang A258. Pada variabel harga, nilai signifikansi dari uji t-nya adalah sebesar 0,003 $<0,05$, sehingga terbukti bahwa variabel harga tersebut berpengaruh positif dan signifikan terhadap keputusan pembelian pada TIKI Tegal Parang A258. Adapun pada variabel pelayanan, diperoleh nilai signifikan sebesar $0,010<0,05$ dari hasil uji t-nya, sehingga variabel pelayanan tersebut terbukti pula berpengaruh positif dan signifikan terhadap keputusan pembelian pada TIKI Tegal Parang A258. 


\section{Pembahasan}

\section{Pengaruh Promosi terhadap Keputusan Pembelian}

Berdasarkan hasil penelitian ini, variabel promosi terbukti berpengaruh positif dan signifikan terhadap keputusan pembelian pada TIKI Tegal Parang A258. Hal tersebut menunjukkan bahwa semakin baik sistem promosi yang dipergunakan oleh perusahaan, maka semakin tinggi tingkat keputusan pembelian yang akan dilakukan oleh konsumen terhadap produk jasa yang ditawarkan oleh perusahaan tersebut. Sebaliknya, semakin buruk sistem promosi yang dipergunakan oleh perusahaan, maka semakin rendah tingkat keputusan pembelian yang akan dilakukan oleh konsumen terhadap produk jasa yang ditawarkan oleh perusahaan tersebut.

Hasil penelitian ini sejalan dengan hasil penelitian yang dilakukan oleh Haryoko (2017) yang berhasil membuktikan bahwa promosi mampu mempengaruhi keputusan pembelian secara positif dan signifikan. Hal tersebut terjadi karena promosi akan membantu perusahaan dalam mengkomunikasikan produknya secara terpadu kepada konsumen, sehingga pada akhirnya mampu mendorong konsumen tersebut untuk membeli dan menggunakan produk yang bersangkutan. Dengan kata lain, promosi yang dilakukan oleh suatu perusahaan mampu mendorong konsumen untuk mengambil keputusan pembelian terhadap produk yang dipromosikan tersebut, termasuk produk dalam bentuk jasa.

\section{Pengaruh Harga terhadap Keputusan Pembelian}

Berdasarkan hasil penelitian ini, variabel harga terbukti berpengaruh positif dan signifikan terhadap keputusan pembelian pada TIKI Tegal Parang A258. Hal tersebut menunjukkan bahwa semakin baik penetapan harga yang dilakukan oleh perusahaan terhadap produk jasa yang ditawarkannya, maka semakin tinggi tingkat keputusan pembelian yang akan dilakukan oleh konsumen terhadap produk jasa yang ditawarkan oleh perusahaan tersebut. Sebaliknya, semakin buruk penetapan harga yang dilakukan oleh perusahaan terhadap produk jasa yang ditawarkannya, maka semakin rendah tingkat keputusan pembelian yang akan dilakukan oleh konsumen terhadap produk jasa yang ditawarkan oleh perusahaan tersebut.

Hasil penelitian ini sejalan dengan hasil penelitian yang dilakukan oleh Masturi dan Hardini (2017) yang berhasil membuktikan bahwa harga mampu mempengaruhi keputusan 
pembelian secara positif dan signifikan. Hal tersebut mencerminkan bahwa pada umumnya, konsumen akan memperhatikan terlebih dahulu harga yang diberikan oleh beberapa perusahaan di industri yang sejenis sebelum akhirnya memutuskan untuk menggunakan produk (barang/jasa) yang ditawarkan oleh satu perusahaan yang paling dikehendakinya. Dalam hal ini, Masturi dan Hardini (2017) berpendapat bahwa harga yang ekonomis cenderung mampu untuk lebih menarik minat beli konsumen. Keduanya menjelaskan bahwa banyak konsumen akan lebih tertarik untuk membeli produk dengan harga bersaing yang juga sebanding dengan manfaatnya.

\section{Pengaruh Pelayanan terhadap Keputusan Pembelian}

Berdasarkan hasil penelitian ini, variabel pelayanan terbukti berpengaruh positif dan signifikan terhadap keputusan pembelian pada TIKI Tegal Parang A258. Hal tersebut menunjukkan bahwa semakin baik pelayanan yang diberikan oleh perusahaan terhadap konsumennya, maka semakin tinggi tingkat keputusan pembelian yang akan dilakukan oleh konsumen tersebut terhadap produk jasa yang ditawarkan oleh perusahaan. Sebaliknya, semakin buruk pelayanan yang diberikan oleh perusahaan terhadap konsumennya, maka semakin rendah tingkat keputusan pembelian yang akan dilakukan oleh konsumen tersebut terhadap produk jasa yang ditawarkan oleh perusahaan.

Hasil penelitian ini sejalan dengan hasil penelitian yang dilakukan oleh Amrullah, dkk. (2016) yang berhasil membuktikan bahwa kualitas pelayanan mampu mempengaruhi keputusan pembelian secara positif dan signifikan. Dalam hal ini, Sari dan Lestari (2019) menjelaskan bahwa konsumen akan merasa puas jika menerima pelayanan yang baik serta sesuai dengan ekspektasinya karena hal itu menunjukkan bahwa perusahaan menghargai konsumen tersebut dan selalu berupaya untuk memenuhi kebutuhan dan keinginannya yang salah satunya diwujudkan melalui pemberian pelayanan yang prima. Oleh sebab itu, konsumen cenderung untuk melakukan pembelian pada perusahaan dengan pelayanan prima yang dinilainya paling sesuai dengan ekspektasinya.

Secara lebih lanjut, Rizaldi dan Hardini (2018) menjelaskan bahwa pelayanan yang berkualitas tinggi juga mampu memberikan kepuasan bagi konsumen. Dengan kata lain, kualitas pelayanan tidak hanya mampu mempengaruhi konsumen untuk melakukan keputusan pembelian, tetapi juga mampu untuk memuaskan konsumen tersebut hingga 
akhirnya bahkan mampu mengkonversi konsumen yang bersangkutan untuk menjadi pelanggan yang loyal.

\section{KESIMPULAN DAN SARAN}

\section{Kesimpulan}

Berdasarkan hasil penelitian dan pembahasan yang telah diuraikan di atas, maka peneliti dapat menarik kesimpulan sebagai berikut.

1. Promosi berpengaruh positif dan signifikan terhadap keputusan pembelian.

2. Harga berpengaruh positif dan signifikan terhadap keputusan pembelian.

3. Pelayanan berpengaruh positif dan signifikan terhadap keputusan pembelian.

\section{Saran}

Berdasarkan kesimpulan di atas, maka peneliti memberikan saran sebagai berikut kepada perusahaan dan para peneliti selanjutnya.

1. Perusahaan disarankan untuk meningkatkan promosi yang dilakukannya, baik dari segi kualitas maupun kuantitas, agar dapat meningkatkan keputusan pembelian konsumen terhadap produk yang ditawarkannya, misalnya dengan cara membuat iklan yang lebih menarik dan melakukan promosi penjualan pada hari-hari tertentu.

2. Dalam rangka meningkatkan keputusan pembelian, perusahaan disarankan untuk senantiasa mengevaluasi harga dari produk-produk yang ditawarkannya agar harga dari produk-produk tersebut sesuai dengan manfaat yang ditawarkannya dan mampu untuk senantiasa bersaing dengan harga dari produk-produk pesaing, sehingga keputusan pembelian

3. Dalam rangka meningkatkan keputusan pembelian, perusahaan disarankan untuk senantiasa memberikan pelayanan yang baik kepada konsumen dan respon yang cepat terhadap setiap kendala yang dialami konsumen, serta memberikan jaminan keamanan yang lebih berkualitas lagi terhadap barang/dokumen milik konsumen yang akan dikirimkan. 


\section{DAFTAR PUSTAKA}

Amrullah, P.S. Siburian, dan S. Zainurossalamia. 2016. Pengaruh Kualitas Produk dan Kualitas Layanan terhadap Keputusan Pembelian Sepeda Motor Honda. Kinerja: Jurnal Ekonomi dan Manajemen. 13(2): 99-118.

Assauri, S. 2015. Manajemen Pemasaran. Edisi Pertama. Rajawali Pers. Jakarta.

Alma, B. 2018. Manajemen Pemasaran dan Pemasaran Jasa. Alfabeta. Bandung.

Fauzi, A. 2017. Pemasaran Internasional: Penganntar, Teori dan Konsep. Edisi Pertama. Empatdua. Malang.

Haryoko, U.B. 2017. Analisis Pengaruh Harga dan Promosi terhadap Keputusan Pembelian Mobil di UJM Motor Tangerang Selatan. Inovasi: Jurnal Ilmiah Ilmu Manajemen. 2(2): 1-20.

Masturi, H. dan R. Hardini. 2017. Pengaruh Kualitas Produk, Harga dan Word of Mouth terhadap Keputusan Pembelian Karate-Gi Merek Hokido di Lima Dojo Wilayah DKI Jakarta. Jurnal Ilmu Manajemen Oikonomia. 13(2): 87-98.

Nasution, N. 2015. Manajemen Mutu Terpadu. Edisi Kedua. Ghalia Indonesia. Jakarta.

Parasuraman, A., V.A. Zeithaml dan L.L. Berry. 1988. SERVQUAL: A Multiple-Item Scale for Measuring Consumer Perceptions of Service Quality. Journal of Retailing. 64(1): 12-40.

Rizaldi, M.L. dan R. Hardini. 2018. Pengaruh Kualitas Pelayanan, Brand Image dan Customer Relationship Management terhadap Loyalitas Pelanggan Indomaret Kelurahan Padurenan, Bekasi Timur. Jurnal Ilmu Manajemen Oikonomia. 14(2): 77-94.

Sari, M.R., dan R. Lestari. 2019. Pengaruh Persepsi Harga, Kualitas Pelayanan, dan Kualitas Produk terhadap Kepuasan dan Dampaknya pada Minat Pembelian Ulang Konsumen Kereta Api Kelas Eksekutif Argo Parahyangan. Jurnal Ilmu Manajemen Oikonomia. 15(1): 30-44.

Sumarwan, U. 2018. Perilaku Konsumen. Edisi Kedua. Universitas Terbuka. Tangerang Selatan.

Sudaryono. 2014. Perilaku Konsumen dalam Prespektif Pemasaran. Lentera Ilmu Cendekia. Jakarta.

Tjiptono, F. 2017. Strategi Pemasaran. Edisi Keempat. Andi Offset. Yogyakarta.

Tjiptono, F. dan G. Chandra. 2016. Service, Quality and Satisfaction. Edisi Keempat. Andi Offset. Yogyakarta. 